\title{
A critical analysis of building sustainability assessment methods for healthcare buildings
}

\author{
Maria de Fátima Castro • Ricardo Mateus • Luís Bragança
}

Received: 8 June 2014/ Accepted: 8 December 2014

(C) Springer Science+Business Media Dordrecht 2014

\begin{abstract}
The healthcare building project contains different aspects from the most common projects. Designing a healthcare environment is based on a number of criteria related to the satisfaction and well-being of the professional working teams, patients and administrators. Mostly due to various design requirements, these buildings are rarely designed and operated in a sustainable way. Therefore, the sustainable development is a concept whose importance has grown significantly in the last decade in this sector. The worldwide economic crisis reinforces the growing environmental concerns as well as raising awareness among people to a necessary and inevitable shift in the values of their society. To support sustainable building design, several building sustainability assessment (BSA) methods are being developed worldwide. Since healthcare buildings are rather complex systems than other buildings, so specific methods were developed for them. These methods are aimed to support decision-making towards the introduction of the best sustainability practices during the design and operation phases of a healthcare environment. However, the comparison between the results of different methods is difficult, if not impossible, since they address different environmental, societal and economic criteria, and they emphasize different phases of the life cycle. Therefore, the aim of this study was to clarify the differences between the main BSA methods for healthcare buildings by analysing and categorizing them. Furthermore, the benefits of these methods in promoting a more sustainable environment will be analysed, and the current situation of them within the context of standardization of the concept sustainable construction will be discussed.
\end{abstract}

Keywords Assessment methods $\cdot$ Healthcare buildings $\cdot$ Life cycle $\cdot$ Sustainability

M. F. Castro $(\bowtie) \cdot$ R. Mateus · L. Bragança

Territory, Environmental and Construction Research Centre (C-TAC), University of Minho, Campus de Azurém, 4800-048 Guimarães, Portugal

e-mail: info@mfcastro.com

R. Mateus

e-mail: ricardomateus@civil.uminho.pt

L. Bragança

e-mail: braganca@civil.uminho.pt 


\section{Introduction}

The health sector has a strong influence on the economy of nations and their policies, incorporating a group of buildings where the quality of the indoor environment is quite significant. The intensive operation of this equipment for $24 \mathrm{~h}$, the high number and movement of people, the existence of distinct work zones with different energy needs, the existence of different functions such as treatment, education, research, rehabilitation, health promotion and disease prevention, the need for the existence of systems strategic reserve of equipment for constant energy supply, and the size of facilities are the key points that differentiate these from other types of buildings and make it a specific case study (Johnson 2010).

According to the Environmental Protection Agency (EPA), a healthcare facility is the second most energy-intensive commercial building type, after the food service industry (Johnson 2010). The high-energy consumption in healthcare buildings is mainly due to their continuous operation, requiring light, heat, energy-intensive ventilation, sterilization and preparation of food. Together with these facts, this type of buildings is responsible for generating a great amount of waste. For example, in the USA, five million tons of solid waste is produced on an annual basis (Johnson 2010). In Portugal, a recent study concluded that hospitals consume an average of $10,000,000 \mathrm{~kW} / \mathrm{h}$ of energy, 120,000 $\mathrm{m}^{3}$ of water and produce $800,000 \mathrm{~kg}$ of waste (Pereira 2013) per year.

At present, there are several studies concerning the sustainable development of healthcare units. However, most of them are oriented to business management or to waste management and energy efficiency, as in the study developed by Murray et al. (2008). Sustainable practices in these buildings are not widespread mainly due to the fact that they are not conventional. Additionally, the implementation of sustainable practices, normally related to the concept of "reduction", is not always very well perceived by society and can generate some resistance (Castro et al. 2012). Several studies and professionals, such us Malkin (2006), also agree that it is possible to work through the weaknesses of actions and measures. Some of them are simple and inexpensive, but capable of reducing the environmental impact. These actions and measures will be presented and discussed in this paper.

\subsection{Importance of sustainability assessment tools and standardization of sustainable construction}

The major reason that promoted the development of systems to support environmental performance assessment of buildings was the effective realization in some countries that they were unable to say how sustainable a building was. This is even true for countries and design teams, which believed that they were experts in the sustainable construction design concept. Later, researchers and government agencies understood that rating systems are the best method to demonstrate the level of sustainability of all types of constructions, including buildings (Haapio and Viitaniemi 2008). These can improve the education for sustainable society, because it can promote understanding between the principles of sustainable construction and the user (Cars and West 2014). Through the years, these systems have contributed to the growth of the awareness about criteria and objectives of sustainability, and they have become a reference to assess the sustainability of buildings in particular and construction in general. According to these systems, a building is a sustainable building when it is built in an ecologically oriented way that reduces its impact on the environment (Berardi 2013). 
Nevertheless, the search for better methods and assessment tools is still ongoing. At present, there are still some uncertainties beyond the constant confusion about the meaning of sustainable construction, which cover, most often, only energy and water efficiencies. Therefore, to clarify and emphasize the best design options, it became essential and urgent to integrate sustainability assessment experts in the design team (Forsberg and von Malmborg 2004).With regard to assessment methods, most of them are based on a holistic sustainability approach, considering only the most representative sustainability indicators, given that the assessment of all links between the natural and artificial environments would lead to an extremely time consuming and impractical process (Conte and Monno 2012).

Within this, several countries have developed their own systems for sustainability assessment adapted to their reality and presenting them as capable of guiding the overall performance of this sector. Most of these systems are based on local rules and legislation, in locally conventional construction technologies, with the default weight of each indicator set according to the actual local socio-cultural, economic and environmental contexts (Crawley and Aho 1999).

These systems are above all oriented to the evaluation of environmental sustainability of buildings, and several authors have discussed their indicators, structure and methods of assessment. For example, Forsberg and von Malmborg (2004) carried out comparative studies of contextual and methodological aspects of tools, Haapio and Viitaniemi (2008) performed a study that analysed and categorized a group of sixteen environmental impact assessment tools, Fowler and Rauch (2006) provided a study that summarized the existing sustainable building rating systems, and Berardi (2011) published a study about sustainability assessment criteria in the construction sector. Additionally, for instance, Mateus and Bragança (2011) and Ali and Al Nsairat (2009) developed a study about the adaptation of global tools to specific countries.

Regarding these studies, it is possible to conclude that the differences between the lists of indicators of the assessment tools make the definition of "sustainable construction" subjective and make it difficult to compare the results obtained from each of the methodologies (Mateus and Bragança 2011). In this context, the International Organization for Standardization (ISO) and the European Committee for Standardization (CEN) have been active in defining standard requirements for the environmental and sustainability assessments of buildings.

The International Organization for Standardization (ISO) has a Technical Committee (TC) 59, "Building and Civil Engineering Works", and a Subcommittee (SC) 17, "Sustainability in Building Construction", which published several standards that are aimed to raise consensus in the definition of sustainable construction. At the same time, CEN has a technical committee (TC) 350, "Sustainability of Construction Works", which is developing standard methods for the assessment of the sustainability characteristics of constructions and standards for the environmental product declarations (EPD) of construction products.

\subsection{Aims and objectives}

At the present time, there are some building sustainability assessment (BSA) tools covering healthcare buildings and there are also studies concerning the structure and content of building environmental and assessment tools in general (indicated in Sect. 1.1). Nevertheless, after analysing the state of the art, it is possible to conclude that there are no specific studies that have analysed and categorized the existing Healthcare Building Sustainability Assessment (HBSA) methods. 
As a result, the aim of this paper was to improve this situation, by analysing and categorizing the existing tools developed specifically to address the sustainability of healthcare buildings. Furthermore, the current situation of these tools in the context of the recent work developed in this field at the CEN and ISO standardization bodies will be analysed, and some development needs will be discussed.

In order to simplify the analysis and understanding of methods, they are analysed in parallel, to allow comparisons and to highlight the main differences. In this context, the tools are going to be categorized according to their goals, users and phases of application, among others, simplifying the understanding about this context and allowing the comparison between them. Additionally, the current situation concerning the methods is discussed and critically analysed in order both to identify their potential in contributing to the sustainability of healthcare buildings and to present some future developments needed to improve their comparability. Finally, topics for further research are discussed.

In summary, the specific objectives of this paper are to:

- analyse and categorize existing HBSA methods;

- study how these methods address the sustainability of healthcare buildings;

- study the similarities and differences between the HBSA methods and how they meet the existing CEN and ISO standards in the context;

- discuss whether the existing HBSA methods address the real needs and specificities of healthcare buildings; and

- discuss the development needs of the BSA methods in the field of healthcare buildings.

\section{Existing healthcare buildings sustainability assessment tools}

There are a growing number of sustainability assessment tools developed for the building sector all over the world focusing on new constructions, existing buildings and refurbishment/rehabilitation operations. But inside these three groups, most assessment tools specify different methods for different types of buildings. In this context, some systems developed specific methods for healthcare buildings. Analysing the state of art concerning HBSA methods, it is possible to identify the following: BREEAM New Construction, LEED for Healthcare, Green Star-Healthcare and CASBEE for New Construction. At the moment, DGNB is still developing a specific methodology for hospitals, but the tool is not finished yet (DGNB 2014), and therefore it was not included in the analysis.

LEED and Green Star have specific methodologies to analyse and evaluate healthcare buildings, with a particular manual and tool: LEED for Healthcare and Green StarHealthcare, respectively. These methodologies have only the specific criteria, benchmarks and weighting system to evaluate and analyse this kind of buildings. On the other hand, BREEAM and CASBEE have a different approach since they have only one manual and tool to be applied to different types of new constructions, including healthcare buildings: BREEAM New Construction and CASBEE for New Construction, respectively. In this second group, there is a list of sustainability criteria to be applied to new constructions, and at the level of each criterion, it specifies the type of building where it must be applied. Nevertheless, in this second group of tools and like in LEED for Healthcare and Green Star-Healthcare, it is also possible to identify the specific criteria, benchmarks and weighting system for healthcare buildings. Therefore, in this paper, LEED for Healthcare and Green Star-Healthcare are compared with the specific criteria, benchmarks and weighting systems to be applied in healthcare buildings according to the other two 
assessment methods. This comparison requires categorizing the tools comparatively. However, such comparisons are not straightforward because while Green Star is a close relative of LEED; on the other hand, CASBEE evaluated the healthcare buildings within a more comprehensive method such as BREEAM.

The tools versions on which this study is based are the latest at the time of submitting this study, namely:

- BREEAM New Construction UK 2011, which was updated in March 2013;

- LEED 2009 for Healthcare, approved in November 2010 and updated in October 2012;

- Green Star-Healthcare v1, originally released in June 2009 and updated in November 2012;

- CASBEE for New Construction 2010 edition.

\section{Categorizing tools by characteristics}

All HBSA tools presented in the last section are being applied. LEED and BREEAM are two of the most popular assessment tools making claims to represent the continents to which they belong, the America and the Europe. The Australia's Green Star is the equivalent of America's LEED, and CASBEE is the Asia's system with wider world presence. All of them are of the same type and belong to the same framework of the assessment tools that are classified in the ATHENA and IEA Annex 31 classification systems. The four tools are integrated in level 3 and class 3, respectively, of these two classification systems: Whole Building Assessment Frameworks or Systems (level 3 ATHENA); Environmental Assessment Framework and Rating Systems (class 3 IEA Annex 31) (Haapio and Viitaniemi 2008). In addition to this classification, it is possible to categorize these four assessment tools according to their contents and characteristics.

Analysing the different tools, it is possible to identify several differences (e.g. goal, users, phase of application, among others), and therefore the emerging role of these kinds of tools encourages discussing them more thoroughly and categorizing them. In this study, it is intended to point out the similarities and the differences between the abovementioned tools to promote their analysis and study, their own development and international consensus and to support the development of future HBSA tools. So, in the following sections, the HBSA methods are categorized by:

- Types of healthcare buildings that are assessed;

- Users of methods;

- Phases of life cycle under assessment;

- Structure and weighting;

- Specific sustainability criteria for healthcare buildings; and

- Classification and communication format of results.

\subsection{Types of healthcare buildings that are assessed}

The healthcare buildings vary greatly according to the medical specialties that are covered, to the activities that are developed in the building, the location of the building, the community that it serves and the economic and financial characteristics that support it. The Green Star, BREAM, LEED and CASBEE rating tools are specifically oriented to the context of their own country of origin. Therefore, there are specific rules for each tool. For 
Table 1 Types of healthcare buildings considered in the studied HBSA methods

\begin{tabular}{|c|c|c|c|c|}
\hline \multirow[t]{2}{*}{ Types of healthcare buildings } & \multicolumn{4}{|c|}{ Assessment methods } \\
\hline & $\begin{array}{l}\text { LEED for } \\
\text { Healthcare }\end{array}$ & $\begin{array}{l}\text { BREEAM } \\
\text { New } \\
\text { Construction }\end{array}$ & $\begin{array}{l}\text { CASBEE for } \\
\text { New } \\
\text { Construction }\end{array}$ & $\begin{array}{l}\text { Green Star- } \\
\text { Healthcare }\end{array}$ \\
\hline Teaching/research/specialist hospitals & $\mathrm{X}$ & $\mathrm{X}$ & & $\mathrm{X}$ \\
\hline General acute hospitals & $\mathrm{X}$ & $\mathrm{X}$ & $\mathrm{X}$ & $\mathrm{X}$ \\
\hline Community and mental health hospitals & $\mathrm{X}$ & $\mathrm{X}$ & $\mathrm{X}$ & \\
\hline GP surgeries & & $\mathrm{X}$ & & \\
\hline Health centres and clinics & $\mathrm{X}$ & $\mathrm{X}$ & $\mathrm{X}$ & $\mathrm{X}$ \\
\hline Homes for elderly & $\mathrm{X}$ & $\mathrm{X}$ & $\mathrm{X}$ & \\
\hline Family support facility & $\mathrm{X}$ & $\mathrm{X}$ & $\mathrm{X}$ & \\
\hline Medical device supplier & $\mathrm{X}$ & & & \\
\hline Home healthcare service provider & $\mathrm{X}$ & & & \\
\hline Healthcare support agencies & $\mathrm{X}$ & & & \\
\hline Rehabilitation facility & $\mathrm{X}$ & $\mathrm{X}$ & $\mathrm{X}$ & \\
\hline
\end{tabular}

example, the building class defined by the Australian National Construction Code (NCC) establishes the type of buildings that are eligible to be rated under the Green Star rating tools.

Bearing this in mind, the four HBSA methods studied are oriented towards inpatient and outpatient care facilities and licensed long-term care facilities. Table 1 presents the several types of healthcare buildings that can be assessed by each of the abovementioned methods.

Unlike the LEED and BREEAM tools, Green Star and CASBEE do not specify specific topics for each type of healthcare building. However, they are all equal regarding the treatment they attach to their criteria, because none of them has specific parameters for any of the different type of healthcare building. There exists only a single analysis grid for all of them.

\subsection{Users of methods}

HBSA methods are being developed for different purposes and for being used for commercial and research proposes, and/or to support decision-making in the construction and rehabilitation of this building typology.

In this context, it is possible to identify the professional groups for which the different tools that are being analysed in this study are oriented. In this paper, the following groups of users are identified: construction professionals (architects, engineers and constructors); producers of building products or materials; building owners and investors; consultants; building users; researchers; and authorities.

The tools studied are of most value to the following groups: construction professionals; consultants; researchers; and authorities (Table 2). LEED for Healthcare tool and BREEAM New Construction tool are the ones that cover the greater number of groups.

Analysing the available information, it is not possible to conclude which of the listed groups use more often these tools. However, it is known that researchers, authorities, construction professionals and also building owners and investors have proven to be the most interested in the potential of study, analysis, response and commercial effects of these tools. Therefore, there is an obvious need to conduct surveys on users of these 
sustainability assessment tools, in order to perceive and analyse which factors influence the choice of a particular tool for each group defined above. The undertaking of those surveys will lead the researchers to important data that influence the users' decision, for example, the importance of rating prices, the degree of access to the tool, the used language and the coverage of the different life cycle phases. Additionally, it is even more important to analyse how each tool and its results are affecting the stakeholders' decision-making.

It is fundamental to highlight that stakeholders' experience together with their opinion must be considered in developing tools, as well as in CEN and ISO standards.

\subsection{Phases of life cycle under assessment}

The building life cycle is divided into different phases. The case of healthcare buildings is not different from other building constructions. However, in each cycle phase, there are specific characteristics that should be taken into account. Regarding the HBSA tools, it is possible to note that they incorporate the phases of life cycle that seem most important to evaluate these kinds of buildings. In this context, and to allow a comparison between all of them, Table 3 shows the life cycle stage considered in this study and assessed by the four tools analysed. Although all the four methodologies include most of the life cycle phases, BREEAM New Construction and LEED for Healthcare have the greater coverage. Curi-

Table 2 Users of methods

\begin{tabular}{lllll}
\hline Users of the tools & \multicolumn{2}{l}{ Assessment methods } & \\
\cline { 2 - 5 } & $\begin{array}{l}\text { LEED for } \\
\text { Healthcare }\end{array}$ & $\begin{array}{l}\text { BREEAM New } \\
\text { Construction }\end{array}$ & $\begin{array}{l}\text { CASBEE for New } \\
\text { Construction }\end{array}$ & $\begin{array}{l}\text { Green Star- } \\
\text { Healthcare }\end{array}$ \\
\hline Construction professionals & $\mathrm{X}$ & $\mathrm{X}$ & $\mathrm{X}$ & $\mathrm{X}$ \\
Producers of building products & $\mathrm{X}$ & & & \\
Building owners and investors & $\mathrm{X}$ & $\mathrm{X}$ & $\mathrm{X}$ & $\mathrm{X}$ \\
Consultants & $\mathrm{X}$ & $\mathrm{X}$ & $\mathrm{X}$ & $\mathrm{X}$ \\
Building users & $\mathrm{X}$ & $\mathrm{X}$ & $\mathrm{X}$ & $\mathrm{X}$ \\
Researchers & $\mathrm{X}$ & $\mathrm{X}$ & $\mathrm{X}$ & $\mathrm{X}$ \\
Authorities & $\mathrm{X}$ & $\mathrm{X}$ & & \\
\hline
\end{tabular}

Table 3 Life cycle phases considered by tools

\begin{tabular}{lllll}
\hline Life cycle phases & \multicolumn{2}{l}{ Assessment methods } & \\
\cline { 2 - 5 } & $\begin{array}{l}\text { LEED for } \\
\text { Healthcare }\end{array}$ & $\begin{array}{l}\text { BREEAM New } \\
\text { Construction }\end{array}$ & $\begin{array}{l}\text { CASBEE for New } \\
\text { Construction }\end{array}$ & $\begin{array}{l}\text { Green Star- } \\
\text { Healthcare }\end{array}$ \\
\hline Project/design & & $\mathrm{X}$ & & $\mathrm{X}$ \\
Production & $\mathrm{X}$ & $\mathrm{X}$ & $\mathrm{X}$ & $\mathrm{X}$ \\
Construction & $\mathrm{X}$ & $\mathrm{X}$ & $\mathrm{X}$ & $\mathrm{X}$ \\
Use/operation & $\mathrm{X}$ & $\mathrm{X}$ & $\mathrm{X}$ & $\mathrm{X}$ \\
Maintenance & $\mathrm{X}$ & $\mathrm{X}$ & & \\
Demolition/deconstruction & $\mathrm{X}$ & $\mathrm{X}$ & & \\
Disposal & $\mathrm{X}$ & $\mathrm{X}$ & & \\
\hline
\end{tabular}


ously, they are distinguished by the fact that one embeds the initial project/design phase and the other the final demolition or deconstruction phase. Differences are primarily related to the specific context of the country for which these methodologies have been developed. To become real work tools, these systems take into account the existing laws in each country, existing standards and the life cycle phases with lower development and support at the level of sustainable development. Although a life cycle phase can be covered by more than one tool, the way it is considered varies from tool to tool. Each system has different criteria to evaluate the sustainability at each phase of the healthcare buildings' life cycle. Consequently, each criterion is differently presented and evaluated, and each tool has its own whole list of criteria. For this reason, it becomes difficult to compare the criteria of each methodology.

\subsection{Structure and weighting}

According to Lee et al. (2002), the structure is the heart of all assessment systems, as it is responsible for establishing the overall performance score. In general, the BSA tools being analysed have the same structure. They all have sustainability assessment categories and indicators and allow the calculation of a single overall score based on a set of weights. The weights are based on the relevance of each category for the sustainability of healthcare buildings, and higher weights are given to indicators of greater importance.

However, there is no unanimity in the weighting considered in these rating systems, since they are not only based on scientific knowledge, but also take into account the experience of various professionals and stakeholders in the area of construction, such as architects, engineers, owners, labour, customers, users, etc. So the weight assigned to each category is different. BREEAM New Construction, LEED for Healthcare and Green StarHealthcare have a similar structure and an identical weighting system. Therefore, they can be compared and Fig. 1 shows how the weight is distributed among each sustainability category in the three HBSA methods.

By analysing CASBEE for New Construction methodology, it is possible to conclude that this is not structured as the other tools, since the assessment is based on the relation between two main groups of criteria: the "building environmental quality" (Q) and the "building environmental load" (LR) (CASBEE 2010). The final weights of these two groups vary according to the final scores obtained at the level attributed of each indicator according to CASBEE coefficients. Therefore, Table 4 presents the weighting coefficients of CASBEE for New Construction.

BREEAM New Construction and Green Star-Healthcare tools are similar regarding the sustainability categories that they cover. Nonetheless, in terms of weight, the distribution of the weights in Green Star-Healthcare tends to resemble LEED for Healthcare, where "energy" and "indoor environmental quality/well-being" categories have more than $50 \%$ of the weight. On the other hand, the same categories in BREEAM New Construction have a weight of around $30 \%$.

Moreover, the BREEAM New Construction tool stands out by having a more balanced weight distribution and for covering a larger number of categories. In second place, it is Green Star-Healthcare. Analysing the different tools, it is possible to conclude that the categories can be structured in the following list of sustainability criteria: (1) management; (2) indoor environmental quality/well-being; (3) service quality; (4) energy; (5) transport; (6) water; (7) materials; (8) waste; (9) sustainable sites; and (10) pollution.

It is also necessary to highlight that in LEED for Healthcare BREEAM New Construction, LEED for Healthcare and Green Star-Healthcare tools are the "innovation" and 


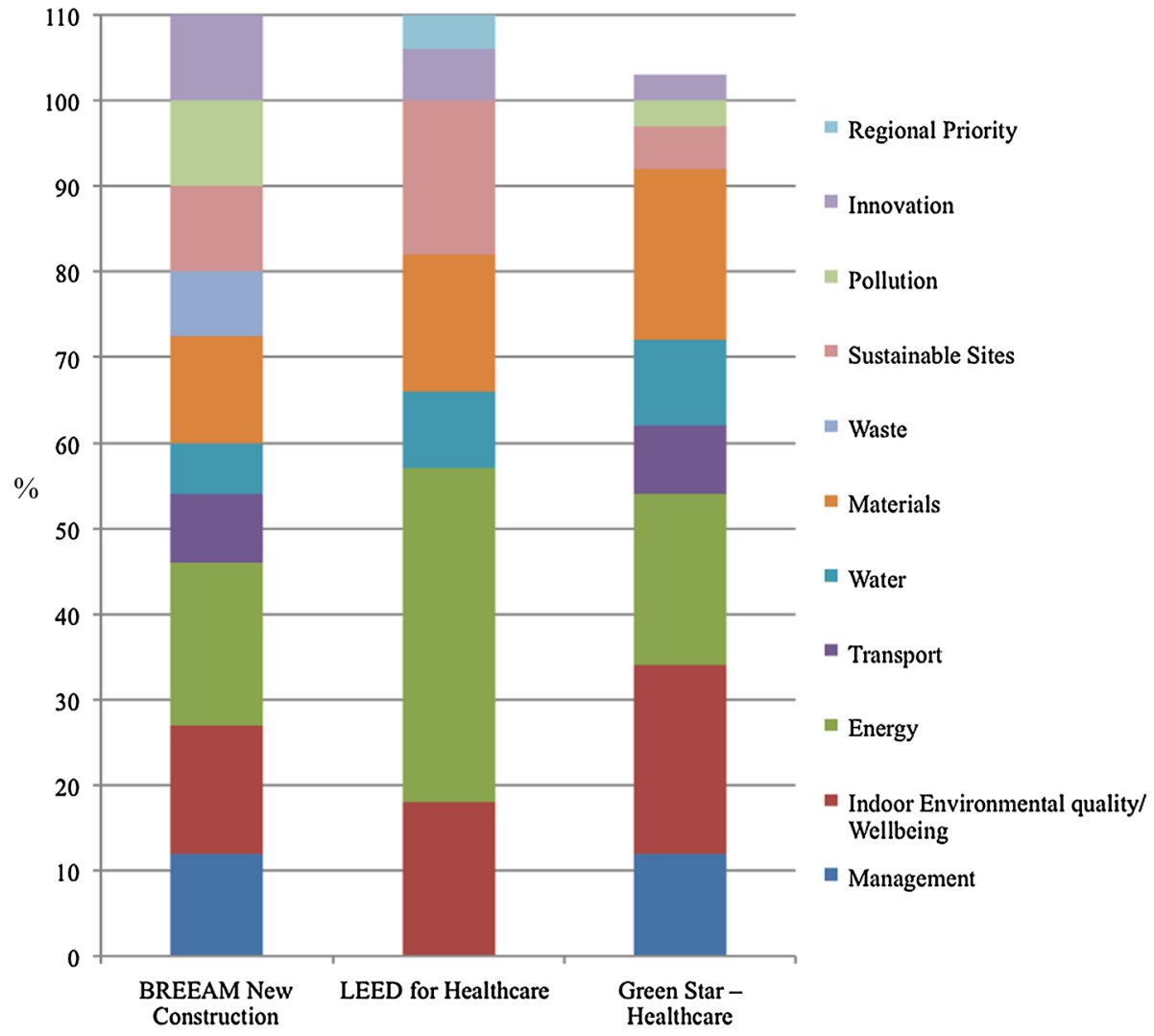

Fig. 1 BREEAM New Construction, LEED for Healthcare and Green Star-Healthcare weights distribution

Table 4 Weighting coefficients of CASBEE for New Construction (CASBEE 2010)

\begin{tabular}{lll}
\hline Assessment categories & Non-factory & Factory \\
\hline Q1 Indoor environment & 0.40 & 0.30 \\
Q2 Quality of service & 0.30 & 0.30 \\
Q3 Outdoor environment on site & 0.30 & 0.40 \\
LR1 Energy & 0.40 & 0.40 \\
LR2 Resources and materials & 0.30 & 0.30 \\
LR3 Off-site environment & 0.30 & 0.30 \\
\hline
\end{tabular}

"regional priority" categories, which recognize projects that achieved innovation and regional priority standards in one or more of the other categories. These two categories allow an additional recognition for a building that innovates in the field of sustainable development and is concerned about the promotion and sustainability of the region, showing a performance above and beyond the level that is currently recognized and rewarded by each methodology. The answer to these categories allows an increase of $10 \%$ 
in the final score, in the case of BREEAM New Construction and LEED for Healthcare and $3 \%$ in case of Green Star-Healthcare (Fig. 1).

For a better comparison between the categories of each methodology, Table 5 presents the main indicators that are embedded in the sustainability categories listed above.

\subsection{Specific sustainability criteria for healthcare buildings}

Analysing the abovementioned methods, it is possible to conclude that they can be divided into two main groups, according to the way they address the criteria for healthcare buildings. In the first group are the methods that have a transversal list of criteria that can be applied to different building types. In the second group, the list of indicators was specifically developed or adapted to only address the sustainability of healthcare buildings.

BREEAM New Construction and CASBEE for New Construction belong to the first group, since they present a single list of criteria that can be applied to all types of new constructions, including healthcare buildings. LEED for Healthcare and Green StarHealthcare belong to the second group, since they only address sustainability criteria related to healthcare buildings.

In the case of BREEAM New Construction, the framework is based on a common list of criteria for different building types. The differences are inside each indicator, since the assessment method, evaluation factors and assigned credits can vary according to the building type.

For example, in the criteria "visual comfort", the credits assigned for the best practices for daylight depend on: "area type", "daylight factor required" and "area to comply". In the case of healthcare buildings, there are still differences between "staff and public areas" and "occupied patient's areas". Additionally, in the criterion "public transport accessibility", the number of credits available for allocation depends on the number and type of public transportation that, according to the evaluation process, each type of buildings should have nearby. In the case of healthcare buildings, its size and importance have also influence in this definition.

Other example is the criterion "proximity to amenities" which assessment also depends on the type of building. For example, in the assessment of the "maximum car parking capacity", the best practice is based on the minimum number of parking spaces allocated for each professional or patient.

The CASBEE for New Construction differs somewhat from the previous method, in the sense that there are some criteria that are only applied to certain building types. Nevertheless, in some indicators such as "sound insulation of partition walls", "daylight factor" and "perceived spaciousness and access to view", the building type influences the assessment process, as in the BREEAM New Construction method.

The methods of the second group, LEED for Healthcare and Green Star-Healthcare, are based on the same core method used in the other methods of each system, but the list of sustainability categories and indicators was developed to specifically address healthcare buildings.

Table 6 presents the criteria of each of these two methods that were developed to specifically address the sustainability of healthcare buildings. These criteria are not present in the core method of each system, namely in the "LEED for New Construction and Mayor Renovations 2009" and in the "Green Star-Multi Unit Residential v1", respectively.

The first group of methods allows easier understanding about the approach used in each system to assess the sustainability, since the sustainability criteria are common to different building types. In this group, the main objective was to standardize the sustainability 
Table 5 Main indicators of the studied HBSA methods

\begin{tabular}{lllll}
\hline Assessment indicators & \multicolumn{2}{l}{ Assessment methods } & \\
\cline { 2 - 4 } & LEED for & BREEAM New & CASBEE for New & Green Star- - \\
& Healthcare & Construction & Construction & Healthcare \\
\hline
\end{tabular}

\section{Management}

Sustainable procurement

$\mathrm{X}$

Responsible construction practices

Construction site impacts

$\mathrm{X}$

$\mathrm{X}$

$\mathrm{X}$

X

Stakeholder participation

$\mathrm{X}$

Service life planning and costing

$\mathrm{X}$

X

Indoor environmental quality/wellbeing

Visual comfort

Indoor air quality

$\mathrm{X}$

$\mathrm{X}$

Thermal comfort

$\mathrm{X}$

$\mathrm{X}$

$X$
$X$

X

$\mathrm{X}$

$\mathrm{X}$

$\mathrm{X}$

Water quality

Acoustic performance

$\mathrm{X}$

$\mathrm{X}$

$\mathrm{X}$

Safety and security

$\mathrm{X}$

$\mathrm{X}$

$\mathrm{X}$

$\mathrm{X}$

Indoor chemical and Pollutant source $\mathrm{X}$

$\mathrm{X}$

X

X control

Service quality

Flexibility and adaptability

Service ability

Durability and reliability

$\mathrm{X}$

$\mathrm{X}$

Energy

Reduction of $\mathrm{CO}_{2}$ emissions

Energy monitoring

X

Low- or zero-carbon technologies

Efficiency in building service system

Natural energy utilization

Renewable energy utilization

Building thermal load

Efficient operation

X

Transport

Public transport accessibility

Cyclist facilities

Car parking capacity

Travel plan

Fuel-efficient transport

Water

Water consumption

$\mathrm{X}$

Water monitoring

Water leak detection and prevention

Water efficiency

Landscape Irrigation

$\mathrm{X}$

X

$\mathrm{X}$

X

$\mathrm{X}$

$\mathrm{X}$

X

$\mathrm{X}$

$\mathrm{X}$

X

X

$\mathrm{X}$

X

X

X

X

X

$\mathrm{X}$

$\mathrm{X}$

X

X

X

X

X

X

X

X X

X

X

X

X 
Table 5 continued

\begin{tabular}{lllll}
\hline Assessment indicators & \multicolumn{3}{l}{ Assessment methods } & \\
\cline { 2 - 4 } & LEED for & BREEAM New & CASBEE for New & Green Star- \\
& Healthcare & Construction & Construction & Healthcare \\
\hline
\end{tabular}

Materials

Life cycle impacts

X

Recycled content of materials

$\mathrm{X}$

X

$\mathrm{X}$

Hard landscaping and boundary

$\mathrm{X}$ protection

Responsible sourcing of materials $\mathrm{X}$

Insulation

Designing for robustness

Reducing usage of non-renewable resources

Avoiding the use of materials with $\mathrm{X}$ pollutant content

Building reuse $\mathrm{X}$

Furniture and medical furnishings $\mathrm{X}$

Design for disassembly

Low-emitting materials $\quad \mathrm{X}$

$\mathrm{X}$

X

$\mathrm{X} \quad \mathrm{X}$

X

X

X

X

X

X

X

X

$\mathrm{X}$

$\mathrm{X}$

X

$\mathrm{X}$

Waste

Construction waste management

X

X

X

Non-hazardous waste

$\mathrm{X}$

Hazardous waste

$\mathrm{X}$

Recycled aggregates

Operational waste

Speculative floor and ceiling finishes

Sustainable sites

Site selection

$\mathrm{X}$

X

X

ecological features

Mitigating ecological impact

X

Enhancing site ecology

Heat island effect

Long-term impact on biodiversity

Townscape and landscape

Local characteristics and outdoor amenity

\section{$\mathrm{X}$}

X

$\mathrm{X}$

X

X

$\mathrm{X}$

X

$\mathrm{X}$

X

$\mathrm{X}$

$\mathrm{X}$

X

$X$
$X$

X

$\mathrm{X}$

X X

\section{Pollution}

Impact of refrigerants

Emissions

Storm water design

Light pollution reduction

Noise attenuation

$\begin{array}{llll} & X & & X \\ X & X & X & X \\ X & X & & X \\ X & X & X & X \\ X & X & X & \end{array}$


Table 6 Specific sustainability criteria for healthcare buildings, considered in LEED for Healthcare and Green Star-Healthcare

Specific sustainability criteria for healthcare buildings

Assessment methods

\begin{tabular}{ll}
\hline LEED for & Green Star- \\
Healthcare & Healthcare
\end{tabular}

Management

Maintainability

$\mathrm{X}$

Construction indoor air quality plan

$\mathrm{X}$

Sustainable procurement guide

$\mathrm{X}$

Indoor environmental quality/well-being

Hazardous material removal or encapsulation $\quad \mathrm{X}$

(renovations only)

Acoustic environment

$\mathrm{X}$

Low-emitting materials

$\mathrm{X}$

Ventilation rates

X

Air change effectiveness

$\mathrm{X}$

$\mathrm{CO}_{2}$ monitoring and control and VOC monitoring

$\mathrm{X}$

Mould prevention

$\mathrm{X}$

Daylight glare control

$\mathrm{X}$

High-frequency ballasts

$\mathrm{X}$

External views

$\mathrm{X}$

Exhaust riser

$\mathrm{X}$

Air distribution system

$\mathrm{X}$

Outdoor pollutant control

$\mathrm{X}$

Places of respite

$\mathrm{X}$

\section{Energy}

Community contaminant prevention—airborne releases

X

Energy sub-metering

$\mathrm{X}$

Lighting zoning

$\mathrm{X}$

Car park ventilation

$\mathrm{X}$

Efficient external lighting

$\mathrm{X}$

Transport

Transport design and planning

$\mathrm{X}$

Water

Minimize potable water use for medical equipment cooling

Water use reduction: measurement and verification

Water use reduction—building equipment, cooling

$\mathrm{X}$ towers and food waste systems

Water metres

$\mathrm{X}$

Potable water use for equipment

$\mathrm{X}$

Materials

PBT source reduction-mercury, mercury in lamps and lead, cadmium and copper

Furniture and medical furnishings

Resource use-design for flexibility 
Table 6 continued

\begin{tabular}{lll}
\hline Specific sustainability criteria for healthcare buildings & \multicolumn{1}{l}{ Assessment methods } \\
\cline { 2 - 3 } & LEED for & $\begin{array}{c}\text { Green Star- Healthcare } \\
\text { Healthcare }\end{array}$ \\
\hline Loose furniture & & $\mathrm{X}$ \\
Celling, walls and partitions & $\mathrm{X}$ \\
$\begin{array}{l}\text { Waste } \\
\text { Construction waste management }\end{array}$ & $\mathrm{X}$ \\
$\begin{array}{l}\text { Non-hazardous waste } \\
\text { Hazardous waste } \\
\text { Recycled aggregates }\end{array}$ & $\mathrm{X}$ & $\mathrm{X}$ \\
$\begin{array}{l}\text { Sustainable sites } \\
\text { Connection to the natural world-places of respite and } \\
\text { direct access for patients }\end{array}$ & $\mathrm{X}$ & \\
$\begin{array}{l}\text { Pollution } \\
\text { Watercourse pollution } \\
\text { Trade waste pollution }\end{array}$ & $\mathrm{X}$ & $\mathrm{X}$ \\
\hline
\end{tabular}

assessments among different building types, simplifying the use and understanding. Nevertheless, it leaves apart criteria that are only important in buildings of this nature.

The second approach aims to get closer to the specific needs of this kind of buildings, presenting specific criteria for their assessment.

\subsection{Classification and communication format of results}

In general, BSA methods are characterized by assessing a number of partial building features and aggregating these results into an environmental rating or sustainability score (Assefa et al. 2010). Nevertheless, the classification methods and the communication format vary from tool to tool.

In the assessment methods studied, the classification methodologies are similar since they are all based upon credits, i.e. there are a number of credits allocated to each sustainability criterion. In LEED and Green Star, the maximum number of credits available for each criterion is related to its weight in the overall score, which is expressed by a rating. When, at a level of a criterion, a project satisfies a certain level of performance, a number of credits are gained. The overall performance is based on sum of all gained credits. In LEED, the overall performance level (rating) is expressed in four qualitative levels (from Certified to Platinum) and in Green Star in three ratings (from 4 to 6 star), according to the conditions presented in Table 8 .

In BREEAM, the classification methodology is slightly different from the two last methods, since besides the credits assigned to each criterion, there is a specific weight for each sustainability category. The overall score, expressed through the Environmental Performance Index (EPI), is then a weighted average of the credits obtained in each sustainability category. Based on this index, it is possible to obtain the overall qualitative sustainability level of a healthcare building. There are six qualitative sustainability levels, from unclassified to outstanding (a star rating from 1 to 5 stars is also provided), according to the conditions presented in Table 7. 
Table 7 Rating scales of the analysed HBSA methods

\begin{tabular}{|c|c|c|c|c|}
\hline \multirow[t]{2}{*}{ Rating scale } & \multicolumn{4}{|l|}{ Assessment methods } \\
\hline & $\begin{array}{l}\text { LEED for } \\
\text { Healthcare }\end{array}$ & $\begin{array}{l}\text { BREEAM New } \\
\text { Construction }\end{array}$ & $\begin{array}{l}\text { CASBEE for New } \\
\text { Construction }\end{array}$ & $\begin{array}{l}\text { Green Star- } \\
\text { Healthcare }\end{array}$ \\
\hline $1^{\circ}$ level (higher level) & $\begin{array}{l}\text { Platinum } \\
80 \text { points and above }\end{array}$ & $\begin{array}{l}\text { Outstanding } \\
5 \text { star } \\
\geq 85 \%\end{array}$ & $\begin{array}{l}\mathrm{S} \\
\mathrm{BEE}=3.0 \text { or more and } \\
\mathrm{Q}=50 \text { or more }\end{array}$ & $\begin{array}{l}6 \text { star } \\
45-59 \text { points }\end{array}$ \\
\hline $2^{\circ}$ level & $\begin{array}{l}\text { Gold } \\
60-79 \text { points }\end{array}$ & $\begin{array}{l}\text { Excellent } \\
4 \text { star } \\
\geq 70 \%\end{array}$ & $\begin{array}{l}\mathrm{A} \\
\mathrm{BEE}=1.5-3.0 \\
\text { or } \\
\mathrm{BEE}=3.0 \text { or more } \\
\text { and } \mathrm{Q} \text { is less than } 50\end{array}$ & $\begin{array}{l}5 \text { star } \\
60-74 \text { points }\end{array}$ \\
\hline $3^{\circ}$ level & $\begin{array}{l}\text { Silver } \\
50-59 \text { points }\end{array}$ & $\begin{array}{l}\text { Very good } \\
3 \text { star } \\
\geq 55 \%\end{array}$ & $\begin{array}{l}\mathrm{B}+ \\
\mathrm{BEE}=1.0-1.5\end{array}$ & $\begin{array}{l}4 \text { star } \\
45-59 \text { points }\end{array}$ \\
\hline $4^{\circ}$ level & $\begin{array}{l}\text { Certified } \\
40-49 \text { points }\end{array}$ & $\begin{array}{l}\text { Good } \\
2 \text { star } \\
\geq 45 \%\end{array}$ & $\begin{array}{l}\mathrm{B}- \\
\mathrm{BEE}=0.5-1.0\end{array}$ & \\
\hline $5^{\circ}$ level & & $\begin{array}{l}\text { Pass } \\
1 \text { star } \\
\geq 30 \%\end{array}$ & $\begin{array}{l}\mathrm{C} \\
\mathrm{BEE}=\text { less than } 0.5\end{array}$ & \\
\hline $6^{\circ}$ level (lower level) & & $\begin{array}{l}\text { Unclassified } \\
<30 \%\end{array}$ & & \\
\hline
\end{tabular}

CASBEE emerges in an odd position since every assessment criterion is weighted in a way that the sum of the weights of the criteria inside each sustainability category is equal to 1 . The score of each indicator is multiplied by the corresponding weighting coefficient and aggregated into total points per category of "Q" or "L" (Table 4) to give the ecoefficiency indicator (BEE), the result of the ratio between "Q" and "L" (CASBEE 2010). Based on the BEE value, the overall sustainability score is expressed in five qualitative levels, from $\mathrm{C}$ to $\mathrm{S}$ (Table 7).

In the end, the way the results are communicated is different in each tool and is based on graphs, tables, grades, certificates and reports. The communication systems are developed in such a way that building occupants or owners easily understand and interpret the performance levels. At the same time, it is easy for clients, designers and other stakeholders to work with.

The final presentation of results and classification is similar in the assessment methods studied. These four tools have grades and certificates accompanied by reports, in most cases. LEED for Healthcare, BREEAM New Construction and Green Star-Healthcare have analogous certificates that present the final score accomplished with the rating of each criterion. In these certificates, we still have a brief presentation of the building and the tool version used for the evaluation. These certificates can be accompanied by a report indicating improvement measures that can be applied to increase the classification of the indicators with the worst performance. In case of CASBEE for New Construction, the system creates in the end a chart that summarizes the results and shows the final score. This chart is presented in a certificate similar to the other three.

The communication of an overall performance level, usually together with the performance level at the level of each category, allows effective comparison between different buildings or design approaches under assessment, when using the same BSA method. The 
comparison of the overall result from different methods is very difficult, because the sustainability criteria and weights are different. According to Cole (1999), the comparison of results should always be done at different levels, listing four types of possible comparisons:

- comparison at the level of each criterion between the declared performance and the specific benchmarks;

- comparison between the performance levels obtained in the several criteria within the same building;

- comparison between the performance level obtained in the same criterion from the assessment of different buildings; and

- comparison of the overall sustainability level of different buildings.

This is only possible if a thorough analysis covering each sustainability category and criterion is made. For this purpose, it is necessary that the communication documents (labels, certificates and reports) objectively present, for all criteria, sustainability categories and each assessed life cycle stage, the partial performance levels together with the overall performance. This is not possible in most of the HBSA methods analysed, since the main communication format (sustainability certificate) used is above all based on an overall single qualitative score. The communication formats should also evolve in order to easily allow the users not only to identify the criteria with the worst performance levels, but also to understand which building features and design choices are contributing more to those results. With these developments, it would be possible to easily compare the results from different HBSA methods and optimize the design approaches in order to achieve higher levels of performance.

\section{The ongoing standardization and the development needs in the field of HBSA methods}

In the last years, ISO and CEN have been very active in developing a definition for the sustainable construction concept. As a result, they have been publishing the set of standards. Analysing these standards, it is possible to conclude that sustainable construction does not only mean improving the environmental performance but also, and above all, seeking an optimized balance between environmental, societal and economic aspects. Nevertheless, from the analysis of Table 5, it is possible to conclude that the four assessment methods under study have an unbalanced amount of criteria within the three sustainability dimensions. Additionally, Table 8 outlines the relation between the sustainability categories of the studied HBSA methods and the three sustainability dimensions (and related potential impacts), according to the division proposed by ISO/AWI 21929 (ISO TS 2010).

Regarding Table 8, there are two columns that stand out immediately for opposite reasons: the "cultural value" aspect with no core sustainability categories in the analysed HBSA methods covering it and the "use/depletion of resources" aspects that is considered by most core sustainability categories. Overall, it is possible to conclude that the environmental dimension is the one with the greater presence in all core categories, except "indoor environmental quality/well-being". After the environmental dimension, the aspects with more relevance in the analysed core sustainability categories are the "satisfaction" (social dimension) and "economic value" (economic dimension). 


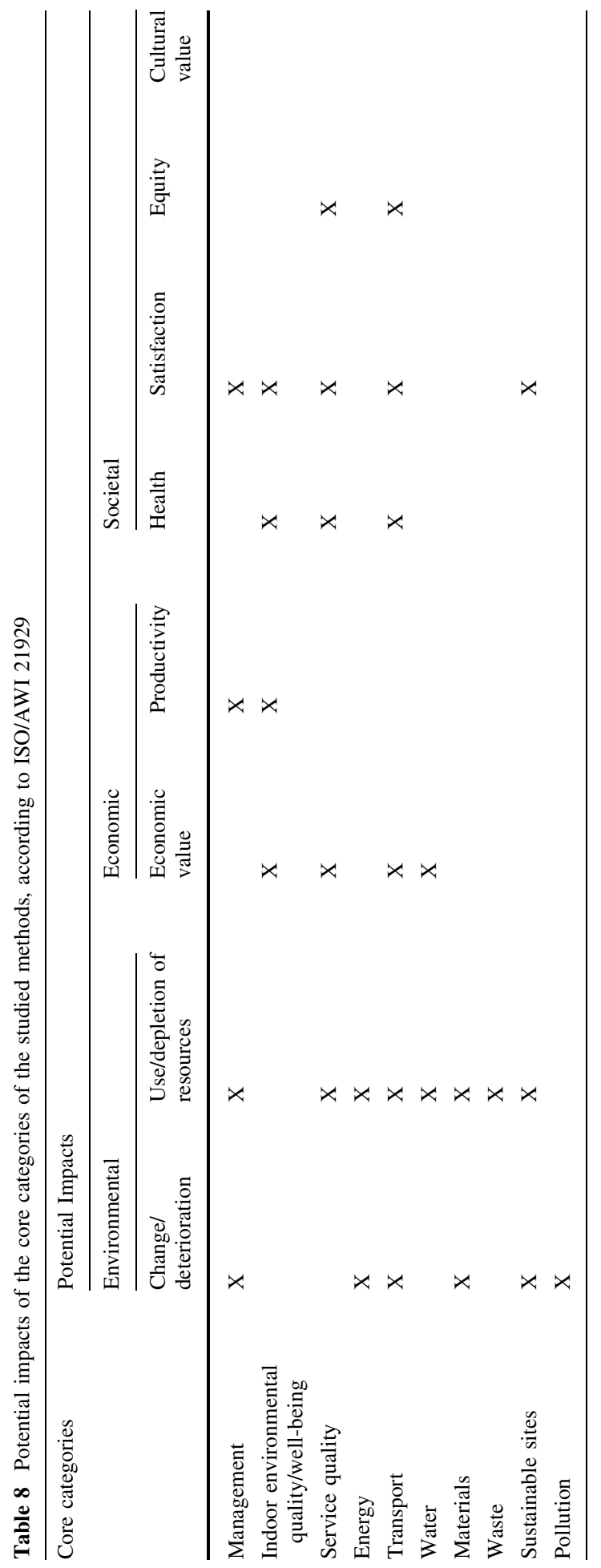


Nevertheless, it is necessary to note that this is a global appreciation that covers the four methodologies being analysed. The individual examination of each one could present some differences, but this is not significant. For example, the "service quality" category is only included in CASBEE for New Construction.

In summary, it is possible to highlight that each indicator or sustainability category can directly or indirectly address more than one economic, environmental or societal impact. For example, the indicators of the category "transport" are related to: the environmental impacts for pollution issues; economic impacts of matters related to fuel costs; and societal impacts because of the need for equal availability and accessibility of transport.

One can say that this is the main cause for the differences between the framework of the BSA methods developed so far, since in one hand, some methods allocate their indicators and sustainability categories into each sustainability dimension, and in other hand, the major part of methods do not do it.

Regarding the standards published in CEN and ISO, a comparative analysis between the methodologies studied and existing standards will be made.

According to CEN/TC 350 mandate, the assessment of the environmental, societal and economic performances of buildings have the following goals (CEN TC 350 2010): to quantify the environmental, societal and economic impacts and aspects of the building and its site; to identify the impacts and aspects of the building and its site; and to enable the client, user and designer to make decisions and choices that will help to address the need for sustainable buildings.

ISO/TC 59/SC 17 (ISO TS 2011) indicates that there are environmental loadings related to environmental, societal or economic impacts. However, it is also possible to use consequential indicators to quantify or qualify the impacts of a building. Taking this into account, Tables 9 and 10 list the environmental, societal and economic aspects that according to ISO/TC 59/SC 17 (ISO TS 2011) and CEN/TC 350 (CEN TC 350 2011, 2012a, b) mandates, respectively, should be considered when assessing the sustainability of construction works. They also present how the four HBSA methods cover the list of the standardized sustainability criteria.

Analysing both Tables 9 and 10, it is possible to conclude that, in order to be in line with standardization developments, the HBSA methods must be restructured in a way that users can have a clear overview about the criteria used to assess the performance at the level of each sustainability dimension. Furthermore, this will allow the development of more balanced weighting systems (within the three dimensions of sustainability), according to the specific context of these types of buildings and country of origin of the HBSA method.

Although the HBSA methods analysed do not address the environmental criteria that describe environmental impacts according to EN 15804: 2012 (CEN TC 350 2012c), they cover directly and indirectly most of the environmental criteria of the other categories: indicators describing resource input; indicators describing resource use, secondary materials and fuels, and use of water; other environmental information describing waste category; and other environmental information describing output flows. From this, it is possible to conclude that these methods have simplified the life cycle impact assessment (LCIA) approach in order to allow non-LCA experts to use them.

In the case of core indicators presented in the ISO standard, it seems that the methods cover almost completely the indicators present in the standard, but this is only due to the fact that these are less detailed. The tools cover some of the concerns presented in one indicator, but not always all the issues. 
Table 9 Sustainability indicators of construction works according to ISO/TC 59/SC 17 (ISO TS 2011) mandate

\begin{tabular}{|c|c|c|c|c|}
\hline \multirow{2}{*}{$\begin{array}{l}\text { Core indicators } \\
\text { ISO 21929-1: } 2011\end{array}$} & \multicolumn{4}{|c|}{ Assessment methods } \\
\hline & $\begin{array}{l}\text { LEED for } \\
\text { Healthcare }\end{array}$ & $\begin{array}{l}\text { BREEAM New } \\
\text { Construction }\end{array}$ & $\begin{array}{l}\text { CASBEE for New } \\
\text { Construction }\end{array}$ & $\begin{array}{l}\text { Green Star- } \\
\text { Healthcare }\end{array}$ \\
\hline \multicolumn{5}{|l|}{ Access to services } \\
\hline Public transportation & $\mathrm{X}$ & $\mathrm{X}$ & & $\mathrm{X}$ \\
\hline Personal modes of transportation & $\mathrm{X}$ & $\mathrm{X}$ & & $\mathrm{x}$ \\
\hline $\begin{array}{l}\text { Green and open spaces } \\
\text { User relevant basic services }\end{array}$ & & & $\mathrm{x}$ & \\
\hline \multicolumn{5}{|l|}{ Aesthetic quality } \\
\hline \multicolumn{5}{|l|}{ Integration with the surrounding } \\
\hline \multicolumn{5}{|l|}{ Impact of building in site } \\
\hline \multicolumn{5}{|l|}{ Local concerns } \\
\hline \multicolumn{5}{|l|}{ Land } \\
\hline Site selection & $\mathrm{X}$ & $\mathrm{X}$ & & $\mathrm{x}$ \\
\hline \multicolumn{5}{|l|}{ Accessibility } \\
\hline Building site & $\mathrm{X}$ & $\mathrm{X}$ & & $\mathrm{X}$ \\
\hline Building & & & $\mathrm{x}$ & \\
\hline \multicolumn{5}{|l|}{ Harmful emissions } \\
\hline Potential impact on climate & $\mathrm{X}$ & $\mathrm{X}$ & $\mathrm{x}$ & $\mathrm{x}$ \\
\hline $\begin{array}{l}\text { Potential impact on the depletion } \\
\text { of stratospheric ozone layer }\end{array}$ & & $\mathrm{X}$ & & $\mathrm{x}$ \\
\hline \multicolumn{5}{|l|}{ Non-renewable resources } \\
\hline Use of resources & $\mathrm{X}$ & & & \\
\hline \multicolumn{5}{|l|}{ Fresh water } \\
\hline Use/consumption & $\mathrm{X}$ & $\mathrm{X}$ & $\mathrm{x}$ & $\mathrm{x}$ \\
\hline \multicolumn{5}{|l|}{ Waste } \\
\hline Production & $\mathrm{X}$ & $\mathrm{X}$ & & $\mathrm{x}$ \\
\hline \multicolumn{5}{|l|}{ Indoor environmental } \\
\hline Indoor conditions & $\mathrm{X}$ & $\mathrm{X}$ & $\mathrm{x}$ & $\mathrm{x}$ \\
\hline Indoor air quality & $\mathrm{X}$ & $\mathrm{X}$ & $\mathrm{x}$ & $\mathrm{x}$ \\
\hline \multicolumn{5}{|l|}{ Safety } \\
\hline Stability & $\mathrm{X}$ & $\mathrm{X}$ & & \\
\hline Resistance & $\mathrm{X}$ & $\mathrm{X}$ & & \\
\hline \multicolumn{5}{|l|}{ Fire safety } \\
\hline \multicolumn{5}{|l|}{ Serviceability } \\
\hline Planning/measurement & & $\mathrm{X}$ & & $\mathrm{x}$ \\
\hline \multicolumn{5}{|l|}{ Adaptability } \\
\hline Adaptability for changed use purpose & & & $\mathrm{x}$ & \\
\hline \multicolumn{5}{|l|}{ Adaptability for climate change } \\
\hline \multicolumn{5}{|l|}{ Costs } \\
\hline Planning/measurement & & $\mathrm{X}$ & & $\mathrm{X}$ \\
\hline \multicolumn{5}{|l|}{ Maintainability } \\
\hline Planning/assessment & & $\mathrm{X}$ & & $\mathrm{x}$ \\
\hline
\end{tabular}


Table 10 Sustainability indicators of construction works according to CEN/TC 350 (CEN TC 350 2011, $2012 \mathrm{a}, \mathrm{b})$ mandate

\begin{tabular}{|c|c|c|c|c|}
\hline \multirow{3}{*}{$\begin{array}{l}\text { Core Indicators } \\
\text { CEN EN 15643-2: } 2011 \\
\text { EN 15643-3: 2012; EN 15643-4: } 2012\end{array}$} & \multicolumn{4}{|c|}{ Assessment methods } \\
\hline & LEED for & BREEAM New & CASBEE for & Green Star- \\
\hline & Healthcare & Construction & New Construction & Healthcare \\
\hline
\end{tabular}

\section{Environmental performance}

Environmental impacts

Global warming potential

Depletion potential of the

$\mathrm{X}$ stratospheric ozone layer

Acidification potential of soil and water sources

Eutrophication potential

Formation potential of tropospheric ozone

Abiotic depletion potential

\section{Resource input}

Use of renewable primary energy

Use of non-renewable primary energy

\section{Resource use}

Use of secondary material

X

$\mathrm{X}$

Use of renewable secondary fuels

Use of non-renewable secondary fuels

Use of net fresh water

$\mathrm{X}$

$$
\text { X }
$$

X

X

Waste

Hazardous waste disposed

Non-hazardous waste disposed

X

X

Radioactive waste disposed

Use of net fresh water

Output flows

Components for re-use

Materials for recycling

Materials for energy recovery

Exported energy

\section{Societal performance}

\section{Accessibility}

For people with specific needs

To building services

X

$$
\text { X }
$$

Adaptability

To accommodate individual user requirements

To accommodate the change of user requirements

To accommodate technical changes

To accommodate the change of use

X 
Table 10 continued

Core Indicators

CEN EN 15643-2: 2011

EN 15643-3: 2012; EN 15643-4: 2012
Assessment methods

\begin{tabular}{llll}
\hline LEED for & BREEAM New & CASBEE for & Green Star- \\
Healthcare & Construction & New Construction & Healthcare
\end{tabular}

Health and comfort

Acoustic characteristics

$\mathrm{X}$

Characteristics of indoor air quality $\mathrm{X}$

Characteristics of visual comfort $\mathrm{X}$

Characteristics of water quality $\mathrm{X}$

Electromagnetic characteristics

Spatial characteristics

Thermal characteristics

$\mathrm{X}$

$\mathrm{X}$

Loadings on the neighbourhood

Noise

Emissions to outdoor air, soil and water

Glare and overshadowing

Shocks and vibrations

Localized wind effects

$\mathrm{X}$

Maintenance

Operations

Safety/security

Resistance to climate change

Resistance to accidental actions

Personal safety and security

$\mathrm{X}$

$\mathrm{X}$

$\mathrm{X}$

X

$\mathrm{X}$

$\mathrm{X}$

$\mathrm{X}$

X X

X

X

X

X

X

X

$\mathrm{X}$

$\mathrm{X}$

$\mathrm{X}$

X

$\mathrm{X}$

X

X

Cost of products supplied at factory gate ready for construction

Costs incurred between factory and site

Professional fees

Temporary and enabling works

X

$\mathrm{X}$

$\mathrm{X}$

$\mathrm{X}$

$\mathrm{X}$

Construction of asset

Initial adaptation or fit out of asset 
Table 10 continued

Core Indicators

CEN EN 15643-2: 2011

EN 15643-3: 2012; EN 15643-4: 2012
Assessment methods

\begin{tabular}{llll}
\hline LEED for & BREEAM New & CASBEE for & Green Star- \\
Healthcare & Construction & New Construction & Healthcare
\end{tabular}

Landscaping, external works on the curtilage

Taxes and other costs related to permission to build

Subsidies and incentives

Economic impacts and aspects excluding the building in operation at the use stage

Building-related insurance costs

Leases and rentals payable to third parties

Cyclical regulatory costs

Taxes

Subsidies and incentives

Revenue from sale of asset or elements, but not part of a final disposal

Third party income during operation

Repairs and replacement of minor components/small areas

Replacement or refurbishment of major systems and components

Adaptation or subsequent fit out of asset-fitting out or modification of existing buildings

Cleaning

Grounds maintenance

Redecoration

Disposal inspections at end-of-lease period

End of lease

Planned adaptation or planned refurbishment of asset in use

Building-related facility management costs

Economic impacts and aspects of the building operational use

Operational energy costs

Operational water costs

Taxes

Subsidies and incentives

Economic impacts and aspects at the end of life

$\begin{array}{llll}X & X & X & X \\ X & X & X & X\end{array}$


Table 10 continued

\begin{tabular}{|c|c|c|c|c|}
\hline \multirow{2}{*}{$\begin{array}{l}\text { Core Indicators } \\
\text { CEN EN 15643-2: } 2011 \\
\text { EN 15643-3: 2012; EN 15643-4: } 2012\end{array}$} & \multicolumn{4}{|c|}{ Assessment methods } \\
\hline & $\begin{array}{l}\text { LEED for } \\
\text { Healthcare }\end{array}$ & $\begin{array}{l}\text { BREEAM New } \\
\text { Construction }\end{array}$ & $\begin{array}{l}\text { CASBEE for } \\
\text { New Construction }\end{array}$ & $\begin{array}{l}\text { Green Star- } \\
\text { Healthcare }\end{array}$ \\
\hline $\begin{array}{l}\text { Deconstruction/dismantling, } \\
\text { demolition }\end{array}$ & & & & $X$ \\
\hline $\begin{array}{l}\text { All transport costs associated with } \\
\text { the process of deconstruction and } \\
\text { disposal of the built asset }\end{array}$ & & & & \\
\hline Fees and taxes & & & & \\
\hline $\begin{array}{l}\text { Costs and/or revenues from reuse, } \\
\text { recycling, and energy recovery at } \\
\text { end of life }\end{array}$ & & & & \\
\hline Revenue from sale land & & & & \\
\hline
\end{tabular}

The development of LCA databases with the environmental criteria that describe the environmental impacts of both different building elements and building integrated technical systems (BITS) is a way to overcome this scenario and to allow the use of more consistent LCA methods, when assessing the environmental performance of buildings. As an example, the SBTool ${ }^{\mathrm{PT}}$ method is based on this approach (Mateus and Bragança 2011).

Analysing the societal criteria, it is possible to conclude that all tools are almost consistent with the EN 15643-3: 2010 and ISO 21929:2011, since they cover most of the listed criteria. Furthermore, from the analysis of Tables 9 and 10, it is also possible to highlight that Green Star-Healthcare is the method with lower development needs and LEED for Healthcare is the one that must be further developed in order to meet all standardized societal criteria. However, the most relevant differences are found at the level of the economic dimension, since most standardized economic criteria are not directly addressed. Rather than assessing directly the standardized economic criteria, the approach used considers that these are implicitly in some environmental principles, such as: reduction of resource consumption; energy management; and water efficiency. Bearing in mind the specific characteristics of healthcare buildings and the differences between the standards and the approaches used, these methods should be developed in order to accommodate clearly the economic criteria. Other important differences between the BSA European Standards (EN 15643-1: 2010, EN 15643-2: 2011, EN 15643-3:2012 and EN 15643-4:2012) and the approach used in the abovementioned HBSA methods are the life cycle stages considered and the way the results are communicated.

According to EN 15643-1: 2010, the building life cycle information model is based on following life cycle stages: product stage (including raw material supply, transport and manufacturing); construction processes (including transport and installation of building materials and products); use stages (including use, maintenance, repair, replacement, refurbishment and both operational energy and water consumption); end-of-life stage (including deconstruction, transport, waste processing and disposal); and benefits and loads beyond the system boundary (including the reuse, recovery and recycling potentials). According to ISO/TR 21932: 2013, the six phases of decision-making process are: strategic planning; project definition; design; construction and handover; operation and maintenance; and end-of-life strategy. 
In the light of these frameworks, the building life cycle starts with the acquisition of raw materials. It proceeds through the manufacture of products, construction work processes, actual use including maintenance, refurbishment and operation of the building, and finally at the end of life, deconstruction or demolition, waste processing in preparation for reuse, recycling and energy recovery and other recovery operations, and disposal of construction materials. Information from these activities is needed to assess the environmental impacts and aspects of the building. Only the benefits and loads beyond the system boundary are considered supplementary information (optional), while all the others are mandatory.

Analysing the list of criteria of the HBSA methods, it is possible to conclude that they not cover all the abovementioned life cycle stages since they are primarily oriented to the product and use stages and roughly address the impacts and benefits resulting from the construction processes and end-of-life stages. According to the CEN/TC 350 standards, the results of an assessment should be expressed using all the criteria given in the environmental, societal and economic standards without any further aggregation of the defined indicators and sustainability dimensions. Furthermore, the results of the assessments shall be organized in the following two main groups: I) impacts and aspects specific to building fabric and site and II) impacts and aspects specific to building in operation. Optionally, supplementary information may be provided in a separate information group: benefits and loads beyond the building life cycle.

The approach considered in the HBSA methods is more in line with ISO standardized requirements, because they present their indicators divided into much broader sustainability categories that cover issues that are related to the three dimensions of the concept of sustainable development (Table 8). But this line is not consistent, because the HBSA methods do not include all categories set out in ISO 21929-1: 2011, and the answer for most categories is not complete, namely: access to services category; aesthetic quality category; safety category; and adaptability. Additionally, from the analysis of the communication format, it is possible to highlight that the HBSA methods are not consistent with the CEN standardized requirements, since they are above all based on a global sustainability score (i.e. the aggregation of sustainability criteria) and do not organize the results in the groups or categories presented. This approach can be justified by the fact that, as a rule, most stakeholders prefer a single, graded scale measure to represent the overall score for a building and to compare different design approaches.

Other important issue is to analyse whether these methods consider all sustainability aspects that are considered relevant by the researchers and practitioners in the specific field of the sustainability of healthcare buildings. This can be made by comparing the list of criteria of these methods with the aspects considered in the design and operation of shining examples of sustainable healthcare buildings. Analysing the abovementioned four HBSA methods, it is possible to conclude that they are based on a holistic sustainability approach, considering only the most representative sustainability criteria, most of them not specific for healthcare buildings. Reasoning for this could be the fact that these methods are the result from the adaptation of methods used to assess conventional buildings types.

\section{Discussion}

In general, the sustainable design of healthcare buildings will result in competitive advantage strategies, as well as better economic, environmental and social efficiency. As 
presented in Fig. 2, more aspects should be considered and integrated during the different life cycle stages of a healthcare building. This multidisciplinary and complex task is only possible through a holistic and systematic approach. At this level, BSA methods play an important role, since they:

1. are developed to consider the most important connections between the built environment and the sustainable development aims;

2. convert the sustainable development aims into objective goals;

3. establish world/regional/national reference and outstanding sustainability practices; and

4. are useful to gather and report information to be used in decision-making processes.

Despite sustainability assessment, this is still an emerging issue in the context of healthcare buildings, because most stakeholders understand BSA methods as an important contribution to support the design, construction and operation phase $\mathrm{s}$ and to recognize the sustainability of residential, commercial and office buildings.

Analysing the BSA methods for healthcare buildings, it is possible to conclude that they:

1. assess the life cycle performance in a different perspective;

2. are based on different sustainability criteria;

3. have different benchmarks;

4. can be applied in different types of healthcare buildings;

5. cover different life cycle stages;

6. use different environmental life cycle assessment databases;

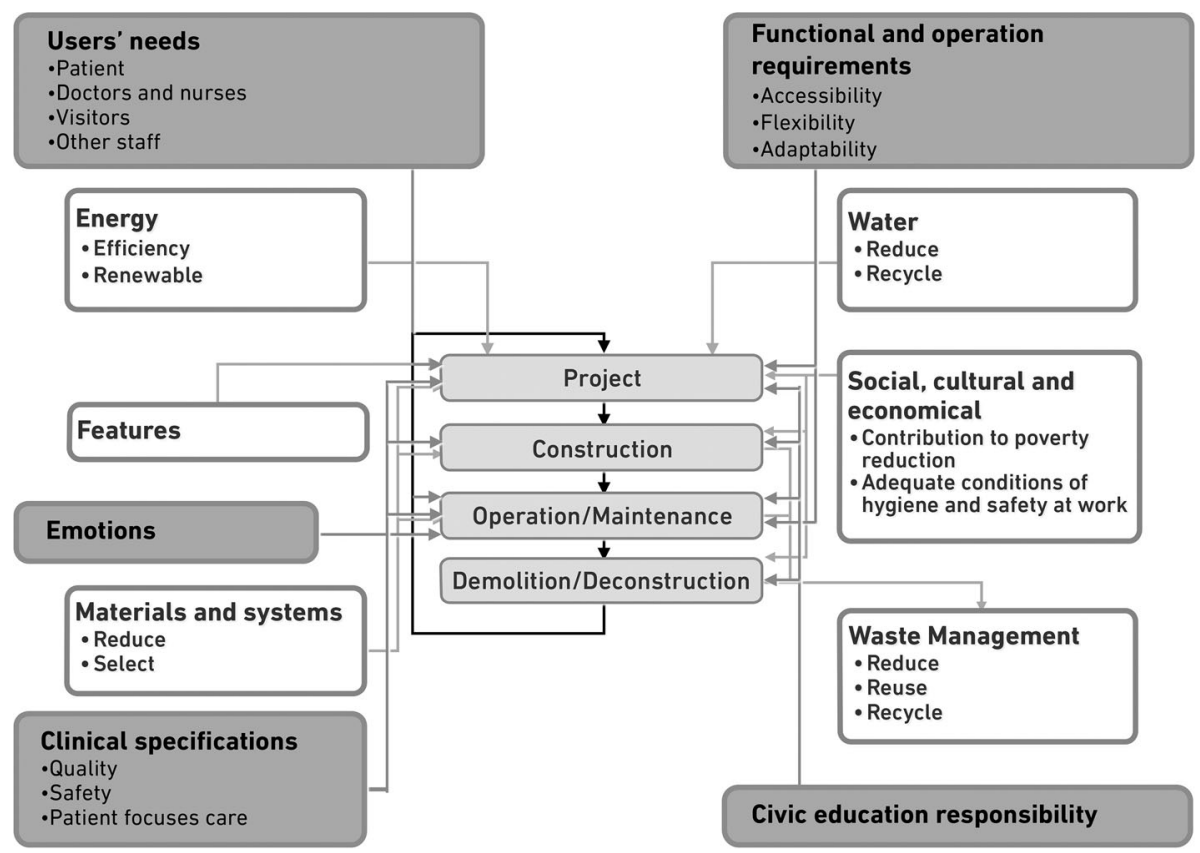

Fig. 2 Life cycle phases of healthcare buildings (Castro et al. 2013a) 


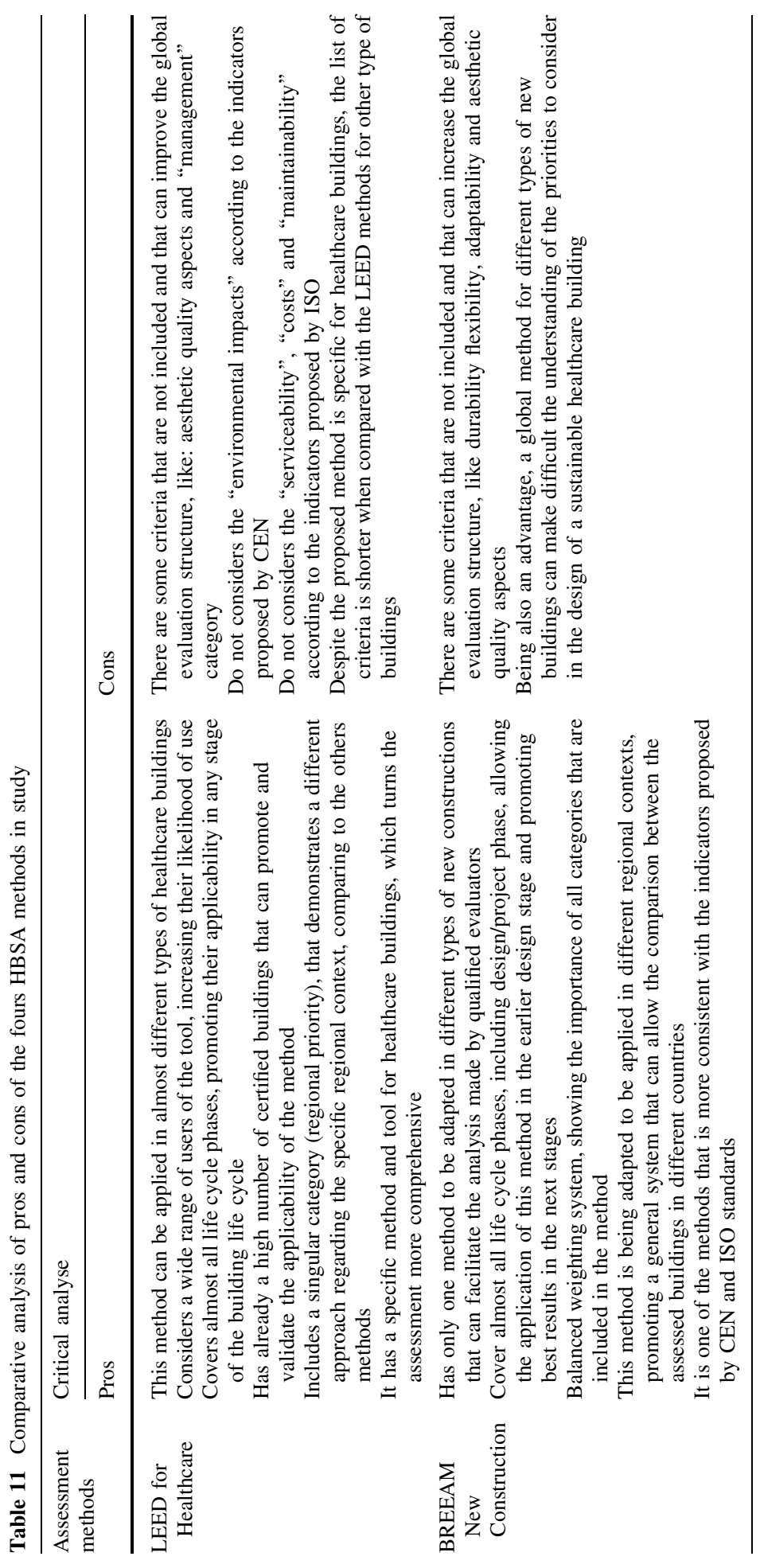




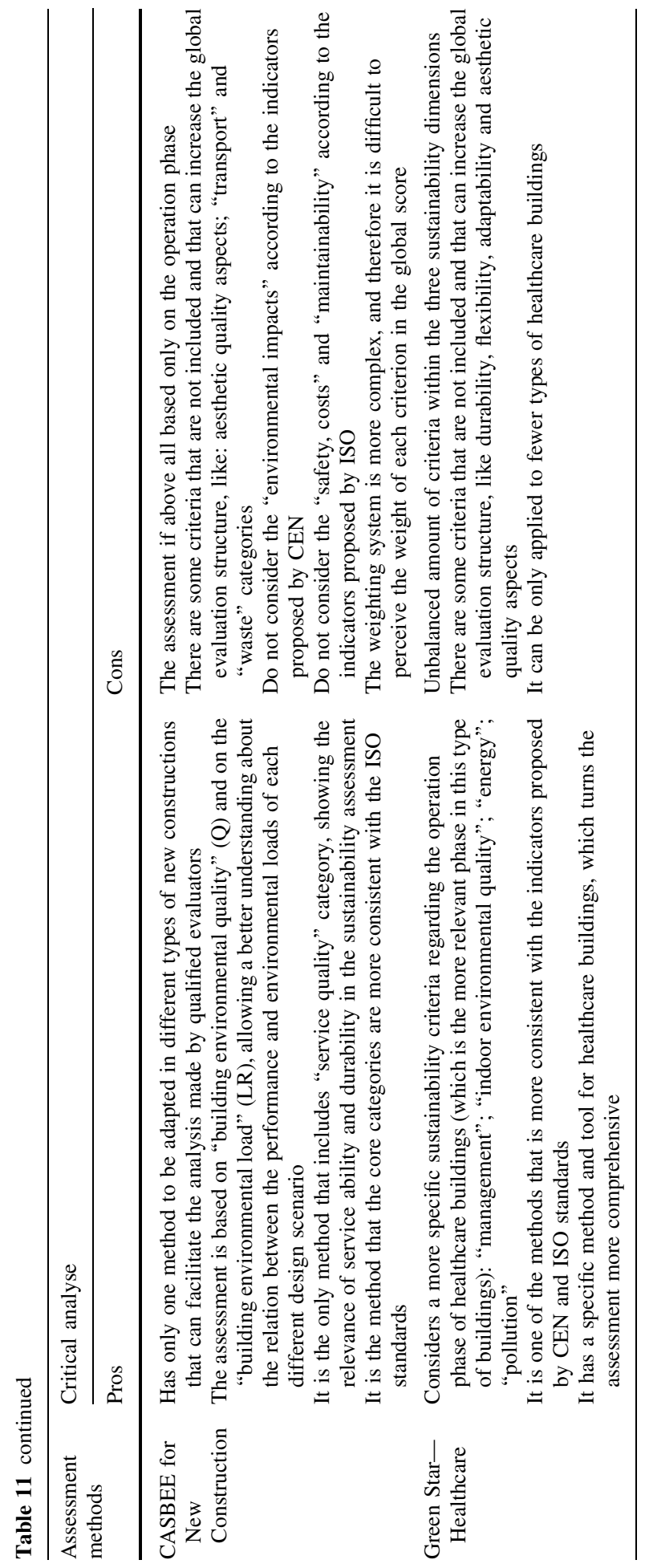


7. use different rating levels; and

8. communicate the results in different ways.

It is also necessary to highlight that according to the intended use, each of the analysed HBSA methods have their own pros and cons, as presented in Table 11.

These differences are above all related to the specific socio-cultural, economic and regulation contexts of the country where each method is being developed and applied. For these reasons, it is possible to conclude that it is very difficult to compare the results from different assessment methods.

In addition to the listed factors, the use of these methods is not yet simple and userfriendly. It is not clear who can use them and how they can be used, where and when they should be used and how the results should be used to support the decision-making in healthcare buildings. Probably, all these aspects are hindering the widespread use of HBSA methods in the design, construction and operation phases of this type of building.

Moreover, there is still an important issue that should be discussed and overcome in order to improve the tools that are studied and presented in this paper: these methods are mainly focused on the environmental issues of the sustainable development concept. Issues between conventional concepts and sustainability make sometimes the mistake of talking only about environment (Buclet and Lazarevic 2014). This can be seen from the way most stakeholders normally refer to these methods: Building environmental assessment tools instead of BSA tools. At the moment, many stakeholders still consider that green building and sustainable building are synonyms. Nevertheless, as presented in Fig. 3, the

Fig. 3 Green building versus sustainable building

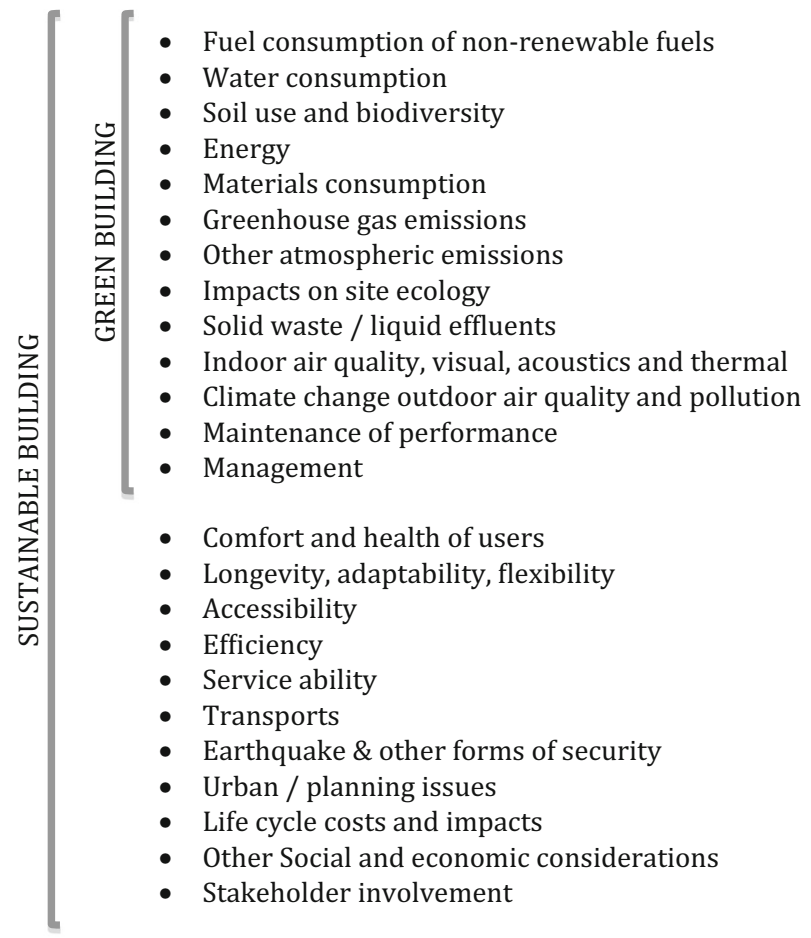


sustainable building concept is much broader and includes several criteria related to the environmental, societal and economic dimensions of sustainable development.

In the case of healthcare buildings, societal issues like comfort and well-being become even more relevant. It should be highlighted that patients should always be in the spotlight and the staff (doctors, nurses, administrative personal, etc.) must have all the necessary conditions to perform their jobs to a high standard. This way, they can evolve to be real BSA methods and to promote a better compatibility between the healthcare buildings and the sustainable development aims.

Therefore, this research work shows that there are emerging aspects that are challenging the future developments in the HBSA methods. First of all, they have to evolve to accommodate the recent standardization works published in the field of the assessment of sustainable construction. From the comparative analysis of the HBSA methods, it is possible to conclude that it is difficult to compare the results from the use of different methods, since they are not based on the same sustainability criteria and use different weighting systems in the aggregation of all criteria for the calculation of the global sustainable score. This barrier can be overcome if the HBSA methods are developed in order to be more consistent with the recent standardization works in the field of the sustainability assessment of construction works, mainly at the level of their structure, list of criteria, process of assessment and the way they communicate the results. Additionally, the way as these methods consider the different sustainability dimensions in the assessment is not the same nor consistent with the standardized definition of sustainable construction. At this level, it is important to highlight that these methods are above all focused in the societal dimension, do not quantify the environmental performance based on the indicators that describe the environmental impacts and the economic dimension is almost ignored. Some solutions to overcome these problems are presented and discussed in the course of this paper.

Other important barrier is that there are some specific sustainability aspects in this type of buildings that are not considered in the best-known HBSA methods and those who design, manage and use this type of buildings consider that important. This can be concluded through the analysis of some recognized case studies (i.e. Boulder Community Foothills Hospital, Providence Newberg Medical Center, Evelina Children Hospital and REHAB Basel) and from the results of previous studies, e.g. Castro et al. (2013b, c).

The four abovementioned case studies are internationally recognized as good practices at the level of sustainable healthcare buildings. Nevertheless, some of the sustainability principles considered relevant by the intervenient in the design process are not recognized by the HBSA methods that exist.

The Boulder Community Foothills Hospital (BCFH) in Colorado, USA, was the first hospital to be assessed by the LEED Healthcare method and was awarded with the "Silver" label. One of the main sustainability principles of this project was to regenerate a decayed industrial area in the city of Colorado, and this positive aspect for the sustainable development is not directly accessed by the analysed HBSA methods. The Providence Newberg Medical Centre was awarded with the rating "Gold" by the LEED method (Gold), and the design process was based on a financial feasibility model (that included all life cycle costs as benefits) for every alternative design scenario. Although the economic performance was considered a very important sustainability principle, as presented in Table 5, none of the studied methods have a life cycle costs sustainability category. The Evelina Children Hospital built in London, UK, was awarded with the NHS Building Better Health Care Award for Hospital Design. The design process included surveys to the young patients of this kind of services, which highlighted an aim for: more user-friendly 
design; nice views to the outside; better interaction and socialization among patients and visitors spaces; and the absence of long corridors, where the patient's expectation grows as they pass through these spaces. These results show, for example, that the indoor programme and spatial organization is an aspect of most importance in the assessment of the societal performance of this kind of buildings. The REHAB Basel hospital located in Basel, Switzerland, is other example that shows that there are some specific societal indicators that should be considered when assessing the sustainability of healthcare buildings. This rehabilitation centre was designed for patients that are hospitalized for an average period of 18 months, usually after a serious accident, aiming a good environment where patients can learn to cope with their new condition of life and to be as independent as possible. Therefore, this building shows the importance of adding some indicators in the sustainability category "quality indoor environment", such as natural lighting and ventilation and organization and interrelation between indoor and outdoor spaces (Guenther and Vittori 2013).

In addition, previous studies developed by Castro et al. (2013b, c) concluded that it is necessary to encourage design teams to incorporate in the programme concerns related to the specific spatial and volumetric organization of indoor and outdoor spaces of this kind of buildings. This is essential to improve "flexibility" and "adaptability" of these buildings and to avoid future problems related to the implementation of new equipment and changes in patients' requirements.

\section{Conclusions}

This paper is the result of a critical review, aimed at comparing the best-known Healthcare Building Sustainability Assessment (HBSA) methods.

The sustainable design, construction and use of buildings are based on the best trade-off between environmental pressure (relating to environmental impacts), social aspects (relating to users' comfort and other social benefits) and economic aspects (relating to life cycle costs). Sustainable design strives for greater compatibility between the artificial and the natural environments without compromising the functional requirements of the buildings and the associated costs.

Based on the environmental, societal and economic relevance of healthcare buildings, different countries and institutions have developed or are in the process of developing domestic assessment methods for this type of buildings.

Facing the challenges highlighted in the discussion chapter of this paper, it is expected that the existing HBSA methods should evolve in order to accommodate some aspects, such as:

- recent developments in the standardization of the sustainability of construction works and buildings (i.e. their sustainability categories, considered life cycle stages and boundaries should be in line standardization works of CEN and ISO);

- a list of sustainability criteria and weighting system that is more balanced between the three dimensions of sustainable development (rather than focusing more in one or two dimensions);

- energy efficiency of the building (considering both renewable and non-renewable consumption during operation phase and in situ renewable energy production);

- specific adaptability and flexibility requirements (for different needs and climate change); 
- life cycle cost analysis of the project (considering the financial costs and benefits of the adopted design principles);

- well-being of patients, medical and administrative staffs (considering in the design phase the health of professionals and patients, who are the users of these buildings, live it and experiment the day-by-day problems);

- and aesthetical quality of building (including the integration of building in the surroundings and impact in site).

Although there are aspects to overcome in all HBSA methods, hindering their adoption, they still have an important role to play, not only in evaluating the impacts of an actual building, but also, and even more importantly, in guiding the appropriate design for the attainment of performance objectives. Adding these criteria to the others presented in Table 5, the HBSA methods can become closer to the essential needs of healthcare buildings.

As final remark, it is expected that the results presented in this paper can contribute to a better understanding in the field of sustainability assessment of healthcare buildings and that can boost further international exchange and coordination in the development of a new generation of HBSA methods.

Acknowledgments The authors acknowledge the Portuguese Foundation for Science and Technology and POPH/FSE for the financial support for this study under the Reference SFRH/BD/77959/2011.

\section{References}

Ali, H. H., \& Al Nsairat, S. F. (2009). Developing a green building assessment tool for developing countries-Case of Jordan. Building and Environment, 44(5), 1053-1064. doi:10.1016/j.buildenv. 2008.07.015.

Assefa, G., Glaumann, M., Malmqvist, T., \& Eriksson, O. (2010). Quality versus impact: Comparing the environmental efficiency of building properties using the EcoEffect tool. Building and Environment, 45(5), 1095-1103. doi:10.1016/j.buildenv.2009.10.001.

Berardi, U. (2011). Sustainability assessment in the construction sector: Rating systems and rated buildings. Sustainable Development, 20(6), 411-424. doi:10.1002/sd.532.

Berardi, U. (2013). Sustainable cities and society. Sustainable Cities and Society, 8, 72-78. doi:10.1016/j. scs.2013.01.008.

Buclet, N., \& Lazarevic, D. (2014). Principles for sustainability: The need to shift to a sustainable conventional regime. Environment, Development and Sustainability. doi:10.1007/s10668-014-9539-4

Cars, M., \& West, E. E. (2014). Education for sustainable society: Attainments and good practices in Sweden during the United Nations Decade for Education for Sustainable Development (UNDESD). Environment, Development and Sustainability. doi:10.1007/s10668-014-9537-6

CASBEE. (2010). CASBEE for New Construction (2010 ed., pp. 1-309). JSBC: Nanjing.

Castro, M. F., Mateus, R., \& Bragança, L. (2012). The importance of the hospital buildings to the sustainability of the built environment. In R. Amoêda, R. Mateus, L. Bragança, \& C. Pinheiro (Eds.), Proceedings of the BSA 2012-1st international conference on building sustainability assessment, Porto, Vol. 1, pp. 857-865.

Castro, M. F., Mateus, R., \& Bragança, L. (2013a). Space design quality and its importance to sustainable construction: The case of hospital buildings. In R. Mateus, L. Bragança, \& M. Pinheiro (Eds.), Proceedings of the Portugal SB13-Contribution of sustainable building to meet EU 20-20-20 targets (1st ed.), Guimarães, Vol. 1, pp. 413-420.

Castro, M. F., Mateus, R., \& Bragança, L. (2013b). Improving sustainability in healthcare with better space design quality. In H. Bártolo (Ed.), Proceedings of the SIM 2013-International conference on sustainable intelligent manufacturing, Lisbon, Vol. 1, pp. 101-106.

Castro, M. F., Mateus, R., \& Bragança, L. (2013c). Indoor and outdoor spaces design quality and its contribution to sustainable hospital buildings (1st ed., Vol.1 pp. 519-522). Proceedings of the CESB 2013-3rd international conference Central Europe towards Sustainable Building, Prague. 
CEN TC 350. (2010). EN 15643-1 sustainability of construction works-Sustainability assessment of buildings_-Part 1: General framework (2010 ed., pp. 1-25). Bruxelas: CEN.

CEN TC 350. (2011). EN 15643-2 Sustainability of construction works-Assessment of buildings-Part 2: Framework for the assessment of environmental performance (2011 ed., pp. 1-35). Bruxelas: CEN.

CEN TC 350. (2012a). EN 15643-3 Sustainability of construction works-Assessment of buildings-Part 4: Framework for the assessment of social performance (2012 ed., pp. 1-29). Bruxelas: CEN.

CEN TC 350. (2012b). EN 15643-4 Sustainability of construction works-Assessment of buildings-Part 4: Framework for the assessment of economic performance (2012 ed., pp. 1-36). Bruxelas: CEN.

CEN TC 350. (2012c). EN 15804 Sustainability of construction works-Environmental product declarations-Core rules for the product category of construction products (2012 ed., pp. 1-49). Bruxelas: CEN.

Cole, R. J. (1999). Building environmental assessment methods: Clarifying intentions. Building Research \& Information, 27(4-5), 230-246. doi:10.1080/096132199369354.

Conte, E., \& Monno, V. (2012). Beyond the building centric approach: A vision for an integrated evaluation of sustainable buildings. Environmental Impact Assessment Review, 34(C), 31-40. doi:10.1016/j.eiar. 2011.12.003.

Crawley, D., \& Aho, I. (1999). Building environmental assessment methods: Applications and development trends. Building Research \& Information, 27(4-5), 300-308. doi:10.1080/096132199369417.

DGNB (Ed.). (2014). Home page of DGNB. Retrieved November 20, 2012, from http://www.dgnb.de.

Forsberg, A., \& von Malmborg, F. (2004). Tools for environmental assessment of the built environment. Building and Environment, 39(2), 223-228. doi:10.1016/j.buildenv.2003.09.004.

Fowler, K. M., \& Rauch, E. M. (2006). Sustainable building rating systems summary (pp. 1-55). Richland: Pacific Northwest National Laboratory, US Department of Energy.

Guenther, R., \& Vittori, G. (2013). Sustainable healthcare architecture (2nd ed.). New Jersey: Wiley.

Haapio, A., \& Viitaniemi, P. (2008). A critical review of building environmental assessment tools. Environmental Impact Assessment Review, 28(7), 469-482. doi:10.1016/j.eiar.2008.01.002.

ISO TS. (2010). ISO/AWI 21929, building construction-Sustainability in building construction-Sustainability indicators - Part 1-Framework for the development of indicators for buildings and core indicators (2010 ed., pp. 1-31). Geneva: ISO.

ISO TS. (2011). ISO/TS 21929-1: 2011, sustainability in building construction-Sustainability indicatorsPart 1: Framework for the development of indicators for buildings (2011 ed., pp. 1-24). Geneva: ISO.

Johnson, S. W. (2010). Summarizing Green Practices in U.S. Hospitals. Hospital Topics, 88(3), $75-81$. doi: $10.1080 / 00185868.2010 .507121$.

Lee, W. L., Chau, C. K., Yik, H. F. W., Burnett, J., \& Tse, M. S. (2002). On the study of the credit-weighting scale in a building environmental assessment scheme. Building and Environment, 37, 1385-1396.

Malkin, J. (2006). Designing a better environmental. In S. Marberry (Ed.), Improving healthcare with better building design (1st ed., pp. 109-124). Chicago: Health Administration Press.

Mateus, R., \& Bragança, L. (2011). Sustainability assessment and rating of buildings: Developing the methodology SBToolPT-H. Building and Environment, 46(10), 1962-1971. doi:10.1016/j.buildenv. 2011.04.023.

Murray, J., Pahl, O., \& Burek, S. (2008). Evaluating the scope for energy-efficiency improvements in the public sector: Benchmarking NHSScotland's smaller health buildings. Energy Policy, 36(3), 1236-1242. doi:10.1016/j.enpol.2007.11.021.

Pereira, M. (2013, December 11). Avaliação do impacte ambiental de edifícios hospitalares portugueses. (R. Mateus \& L. Bragança, Eds.). Escola de Engenharia da Universidade do Minho, Guimarães. 